\title{
Root initiation of bougainvillea from cuttings using different rooting hormones
}

\begin{abstract}
An experiment on stimulation of rooting of six Bougainvillea species using three different rooting hormones was conducted in the nursery, department of crop soil and pest management of the Federal University of Technology Akure, March to June, 2013. The experiment was laid out in Completely Block Design (CRD) and replicated three times. Data were collected on number of days to sprouting, plant height, stem girth, stem length, wet root weight, dry root weight, the number of leaves per cutting and length of longest roots and subjected to Analysis of variance (ANOVA) to determine the level of significance and Tukey Test was used to separate the means. The results showed that the Indole -3-butyric acid and the coconut water had significant effect on the root emergence and root growth of Bougainvillea species compared to the other hormones used and the hard wood cuttings enhanced the rooting of the Bougainvillea compared to the semi -hard wood. Therefore root initiation in cuttings of Boungainvillea could be enhanced with Indole -3-butyric acid (IBA) or dipped in coconut water for 5 minutes and growth was also enhanced using the hard wood cuttings.
\end{abstract}

Keywords: difficult-to-root plants, plant growth regulator, stem cuttings
Volume 9 Issue I - 2019

\author{
Okunlola A lbironke \\ Department of Crop, Soil and Pest Management, Federal \\ University of Technology, Nigeria
}

\begin{abstract}
Correspondence: Okunlola A lbironke, Department of Crop, Soil and Pest Management The Federal University of Technology P.M.B 704 Akure, Ondo State, Nigeria,

Email okunlolaal.hort@gmail.com,smtokunlola@gmail.com
\end{abstract}

Received: May 04, 2017 | Published: January 17, 2019

\section{Introduction}

In the horticultural industry most of perennial ornamental plants are multiplied and propagated vegetative through cuttings, layering or grafting. Generally, the use of cuttings from stems, leaves, roots or terminal buds is considered the most commonly applied technique, due to its practicability and simplicity, especially in a developing country like Nigeria, Okunlola, 2013. Bougainvillea, because of its special characteristics, such as; high variation in type of foliage, production of many flowering inflorescence on one plant and continuous blooming of flowers with short production cycle has been very useful in the ornamental industry (Gordon, 2002). They are widely cultivated as porch, adornments, arbour and ornaments. Their growth habits and beautiful showy bracts make them popular for landscapes. They are also used in mass planting, as shrubs or bushes, ground covers, as hedge plants, barrier plants and slope coverings, in hanging baskets, and in containers for Bonsai. ${ }^{1}$ Though bougainvilleas are primarily propagated by stem cuttings, the success of propagation by stem cutting is very limited; growers observed poor rooting percentage due to lack of competence to form adventitious roots by cuttings which occurs routinely and is an obstacle for their vegetative propagation. ${ }^{2}$ Adventitious root formation is a key step in vegetative propagation of woody or horticultural species, and problems associated with rooting of cuttings frequently result in significant economic losses. ${ }^{1,3}$ preventing growers from realizing the full potential of propagation. ${ }^{4}$ The key to overcoming this challenge is the application of exogenous auxins/rooting hormones. ${ }^{5}$ The commercially available exogenous auxin that aids the formation of adventitious roots are; Indole-3acetic acid (IAA), Indole-3-butyric acid (IBA) and Napthalene Acetic acid (NAA). IBA or NAA or combination of both is recommended for rooting of cuttings and are available in liquid, talc, tablet, and gel formulations. In Nigeria, the major burden of peasant gardeners overcoming the challenge of propagating difficult-to-root plant is the availability, accessibility and cost of procuring these exogenous auxins. They have however devised means to circumvent the problem by using readily available alternatives to IBA and NAA like coconut water, and Tetracycline (Acetysalicylic acid or ASA ); Okunlola, ${ }^{6}$ Hence the study was conducted to examine the effects of a synthetic hormone and alternatives (Tetracycline and coconut water) on the propagation of bougainvillea from cuttings in the nursery.

\section{Materials and method}

The experiment was conducted in the nursery the Department of Cop, Soil and Pest Management the Federal University of Technology, Akure March to June 2013. The state lies between 41300 and 61400 east of the Greenwich meridian and latitudes 501450 and 80 north of the equator. It is located in the rainforest zone with two distinct seasons. The rainfall pattern of Akure is bimodal the mean annual rainfall and number of rainy days were $1495.4 \mathrm{~mm}$ and 110 days respectively. The mean daily maximum and minimum temperatures of the area ranges between $25^{\circ} \mathrm{C}$ and $37^{\circ} \mathrm{C}$. The mean monthly maximum and minimum relative humidity were $83 \%$ and $65 \%$. The site for the nursery was manually cleared and packed using simple farm tools. The nursery was made with bamboos and covered with palm fronds in 10 $\mathrm{cm}$ by $10 \mathrm{~cm}$ spaces. The media used were sand obtained from CSP horticultural garden and forest topsoil. The top soil and sand were sieved to get rid of stones and other extrogenous materials, also to improve aeration and porosity. The growing medium was prepared by mixing equal ratio of sand, and forest topsoil in the ratio of $1: 1$ $(\mathrm{v} / \mathrm{v})$. Equal volume of the growing media was filled in perforated polythene bags of size $(20 \mathrm{~cm}$ by $12 \mathrm{~cm})$, tightly leaving $2.5 \mathrm{~cm}$ space at the top. Before cuttings were inserted into the different media, they were moistened and allowed to settle overnight. A dibber was used to create a hole for the insertion of the cuttings. The stem cuttings of six different variegated varieties i.e the bract color (pink, red, double color, orange, white and purple), about $20 \mathrm{~cm}$ in length were obtained from healthy parent stock very early in the morning (to ensure the plant is fully turgid) with a sharp thin-bladed pocket knife, a smooth cut in each cutting was given on distal end and slanting cut was given at lower end just below the node. The basal ends of the cuttings were dipped in IBA solution by quick dip method for 60 seconds before planting them in the rooting medium. 
The solution was prepared by dissolving the IBA compound in $95 \%$ ethanol and adding distilled water. Also, 3 Tetracycline capsules $(750 \mathrm{mg})$ were dissolved in $250 \mathrm{ml}$ of water and The coconut water from young green tender coconuts was extracted by poking holes in the "eyes" located on the side of the coconut fruits so that the liquid can remain fresh and retain its essential nutrients $100 \mathrm{ml}$ of the fresh coconut water was measured and then poured into a clean bowl with the stem cuttings dipped in this solution for 5 minutes. The experiment was laid out in a Completely Randomized Design (CRD) and replicated three times. The treatments were: cutting types Hardwood and Semi hardwood cuttings; rooting hormone IBA, coconut water, tetracycline, control (no application); stem cuttings of six different varieties (colour). One cutting was planted in each polythene bag making a total of 144 pots. The data were collected on; length of longest root $(\mathrm{cm})$; number of days to sprouting by counting; number of leaves per cutting (by counting); plant height (cm) using metre rule; Stem girth size $(\mathrm{cm})$ using vernier calliper; Root fresh and dry weight $(\mathrm{g})$ were measured using a sensitive Mettler top-loading balance. The data were subjected to analysis of variance, (ANOVA) and means separated using Duncan's Multiple Range Test (DMRT).

\section{Results}

\section{Effect of wood cuttings on stem girth of Bougainvillea spectabilis}

The stem girth of Bougainvillea spectabilis cuttings were significant $(\mathrm{p}<0.05)$. At week 3, Orange (hard wood) and both White (hard wood) and White (semi-hard wood) had the highest and lowest stem girth of $0.66 \mathrm{~cm}, 0.07 \mathrm{~cm}$ and $0.07 \mathrm{~cm}$ respectively. At week 6 , both Red (hard wood) and Orange (hard wood) and Double colour (semi-hard wood) had the highest and lowest stem girth of $0.70 \mathrm{~cm}$, $0.68 \mathrm{~cm}$ and $0.28 \mathrm{~cm}$ respectively. At week 9 , Red (hard wood) and White (semi-hard wood) had the highest and lowest stem girth of $0.88 \mathrm{~cm}$ and $0.42 \mathrm{~cm}$ respectively. There were no significant difference in the mean separation of Purple (semi-hard wood), Double colour (semi-hard wood), Red (hard wood) and Pink (hard wood) as they had stem girth of $0.72 \mathrm{~cm}, 0.72 \mathrm{~cm}, 0.71 \mathrm{~cm}$ and $0.69 \mathrm{~cm}$ respectively. At week 12, Purple (hard wood) and both White (hard wood), Pink (semi-hard wood), Red (semi-hard wood), Pink (hard wood), Double colour (semi-hard wood) and Orange (semi-hard wood) had the highest and lowest stem girth of $0.54 \mathrm{~cm}, 0.52 \mathrm{~cm}, 0.48 \mathrm{~cm}, 0.48 \mathrm{~cm}$, $0.47 \mathrm{~cm}$ and $0.46 \mathrm{~cm}$ respectively as shown in Table 1 .

\section{Effect of wood cuttings on leaf number of Bougainvillea spectabilis}

The effects of wood cuttings of the leaf number of Bougainvillea spectabilis were significant $(\mathrm{p}<0.05)$. At week 3 , Orange (hard wood), Red (hard wood) and Orange (semi-hard wood) had the highest number of leaves of 4.80, 4.48 and 4.26, while White (semi-hard wood) had the lowest number of leaves of 0.64 . At week 6, Purple (hard wood) and White (semi-hard wood) had the highest and lowest number of leaves of 8.48 and 3.02 respectively. At week 9, Purple (hard wood) and White (hard wood) had the highest and lowest number of leaves of 14.29 and 4.56 respectively. At week 12, Purple (hard wood) and Pink (semi-hard wood) had the highest and lowest number of leaves of 14.04 and 5.39 respectively. However, the mean separation of all the treatments did not show significant difference except for Purple (hard wood) and Purple (semi-hard wood) as shown in Table 2.

Table I Effect of wood cuttings on stem girth of Bougainvillea spectabilis

\begin{tabular}{|c|c|c|c|c|}
\hline Treatment & Stemgirth 3WAP & Stemgirth 6WAP & Stemgirth 9 WAP & Stemgirth I2WAP \\
\hline Pink (hard wood) & $0.36 \pm .14 \mathrm{bcd}$ & $0.52 \pm .24 \mathrm{abcd}$ & $0.69 \pm .36 \mathrm{abc}$ & $0.48 \pm .05 d$ \\
\hline Red (hard wood) & $0.50 \pm .05 b$ & $0.70 \pm .8 \mathrm{la}$ & $0.88 \pm .06 \mathrm{a}$ & $0.66 \pm .05 \mathrm{bcd}$ \\
\hline Double color (hard wood) & $0.39 \pm .04 b c$ & $0.49 \pm .7 \mathrm{lbcde}$ & $0.60 \pm .46 \mathrm{bc}$ & $0.67 \pm .04 \mathrm{bcd}$ \\
\hline Orange (hard wood) & $0.66 \pm .04 a$ & $0.68 \pm .2 \mathrm{la}$ & $0.79 \pm .05 \mathrm{ab}$ & $0.87 \pm .76 \mathrm{ab}$ \\
\hline White (hard wood) & $0.07 \pm .05 \mathrm{e}$ & $0.37 \pm .02 \mathrm{cdef}$ & $0.49 \pm .02 \mathrm{de}$ & $0.54 \pm .88 \mathrm{~d}$ \\
\hline Purple (hard wood) & $0.35 \pm .24 \mathrm{bcd}$ & $0.65 \pm .02 \mathrm{ab}$ & $0.84 \pm .53 \mathrm{ab}$ & $0.92 \pm .43 a$ \\
\hline Pink (semi-hard wood) & $0.24 \pm .52 \mathrm{~cd}$ & $0.36 \pm .63 c d e f$ & $0.46 \pm .7 I \mathrm{de}$ & $0.52 \pm .57 d$ \\
\hline Red (semi-hard wood) & $0.29 \pm .08 c d$ & $0.60 \pm .4 \mathrm{Iab}$ & $0.7 I \pm .83 a b c$ & $0.48 \pm .94 d$ \\
\hline Double color (semi-hard wood) & $0.21 \pm .43 \mathrm{de}$ & $0.28 \pm .08 f$ & $0.72 \pm .07 a b c$ & $0.47 \pm .25 d$ \\
\hline Orange (semi-hard wood) & $0.33 \pm .09 \mathrm{~cd}$ & $0.33 \pm .09 \mathrm{def}$ & $0.49 \pm .30 \mathrm{de}$ & $0.46 \pm .3 \mathrm{Id}$ \\
\hline White (semi-hard wood) & $0.07 \pm .07 e$ & $0.32 \pm .0 \mathrm{l} \mathrm{ef}$ & $0.42 \pm .25 \mathrm{e}$ & $0.52 \pm .86 \mathrm{~d}$ \\
\hline Purple (semi-hard wood) & $0.36 \pm .04 \mathrm{bc}$ & $0.55 \pm .32 \mathrm{abc}$ & $0.72 \pm .0 \mathrm{labc}$ & $0.78 \pm .80 \mathrm{abc}$ \\
\hline
\end{tabular}

Table 2 Effect of wood cuttings on number of leaves of Bougainvillea spectabilis

\begin{tabular}{lllc}
\hline Treatment & Leaf number 3WAP & Leaf number 6WAP & Leaf number 9WAP \\
\hline Pink (hard wood) & $3.94 \pm .34 \mathrm{ab}$ & $5.02 \pm .64 \mathrm{cdef}$ & $8.37 \pm .5 \mathrm{Ibc}$ \\
Red (hard wood) & $4.48 \pm .44 \mathrm{a}$ & $7.48 \pm .43 \mathrm{ab}$ & $7.9 \mathrm{I} \pm .52 \mathrm{bc}$ \\
Double color (hard wood) & $3.32 \pm .37 \mathrm{ab}$ & $3.45 \pm .73 \mathrm{efg}$ & $7.56 \pm .83 \mathrm{~b}$ \\
Orange (hard wood) & $4.80 \pm .32 \mathrm{a}$ & $5.48 \pm .49 \mathrm{~cd}$ & $7.02 \pm .43 \mathrm{cde}$ \\
White (hard wood) & $0.64 \pm .84 \mathrm{~d}$ & $3.07 \pm .43 \mathrm{fg}$ & $7.94 \pm .76 \mathrm{~b}$ \\
\hline
\end{tabular}


Table Continued....

\begin{tabular}{lllll}
\hline Treatment & Leaf number 3WAP & Leaf number 6WAP & Leaf number 9WAP & Leaf number I 2WAP \\
\hline Purple (hard wood) & $3.45 \pm .54 \mathrm{ab}$ & $8.48 \pm .42 \mathrm{a}$ & $14.29 \pm .58 \mathrm{a}$ & $14.04 \pm .72 \mathrm{a}$ \\
Pink (semi-hard wood) & $2.47 \pm .63 \mathrm{bc}$ & $3.29 \pm .38 \mathrm{defg}$ & $4.60 \pm .52 \mathrm{de}$ & $5.39 \pm .89 \mathrm{~b}$ \\
Red (semi-hard wood) & $3.70 \pm .36 \mathrm{ab}$ & $5.53 \pm .75 \mathrm{bc}$ & $6.32 \pm .82 \mathrm{cde}$ & $5.99 \pm .56 \mathrm{~b}$ \\
Double color (semi-hard wood) & $1.51 \pm .74 \mathrm{~cd}$ & $2.94 \pm .26 \mathrm{~g}$ & $4.89 \pm .53 \mathrm{de}$ & $7.77 \pm .75 \mathrm{~b}$ \\
Orange (semi-hard wood) & $4.26 \pm .32 \mathrm{a}$ & $5.32 \pm .86 \mathrm{cde}$ & $7.91 \pm .55 \mathrm{bc}$ & $6.34 \pm .97 \mathrm{~b}$ \\
White (semi-hard wood) & $0.64 \pm .36 \mathrm{~d}$ & $3.02 \pm .4 \mathrm{lg}$ & $6.56 \pm .59 \mathrm{cde}$ & $8.15 \pm .44 \mathrm{~b}$ \\
Purple (semi-hard wood) & $3.43 \pm .34 \mathrm{ab}$ & $6.80 \pm .4 \mathrm{labc}$ & $9.97 \pm .52 \mathrm{~b}$ & $12.37 \pm .42 \mathrm{a}$ \\
\hline
\end{tabular}

The effect of cuttings on the fresh root weight of Bougainvillea spectabilis was significant $(\mathrm{p}<0.05)$. The root weight was highest for Purple (hard wood) and lowest for Double color (semi-hard wood). There were no significant difference between Pink (semi-hard wood), Pink (hard wood) and Orange (hard wood), they had root weight of $7.13 \mathrm{~g}, 7.30 \mathrm{~g}$ and $7.35 \mathrm{~g}$ respectively. Also, there were no significant difference between Orange (semi-hard wood), White (semi-hard wood) and Purple (semi-hard wood) they have wet root weight of $5.16 \mathrm{~g}, 5.46 \mathrm{~g}$ and $5.43 \mathrm{~g}$ respectively. The effect of cuttings on the dry root weight of Bougainvillea spectabilis were significant $(\mathrm{p}<0.05)$.
Dry root weight for Pink (hard wood) had the highest value and lowest value was recorded for both White (semi-hard wood) and Double color (hard wood) $0.92 \mathrm{~g}, 0.33 \mathrm{~g}$ and $0.33 \mathrm{~g}$ respectively. There was no significant difference between Red (hard wood), Orange (hard wood), Purple (hard wood) and Purple (semi-hard wood), they had dry root weight of $0.57 \mathrm{~g}, 0.60 \mathrm{~g}, 0.70 \mathrm{~g}$ and $0.54 \mathrm{~g}$ as shown in Table $3 \& 4$. The effect of stem cuttings on the root length of Bougainvillea spectabilis was significant $(\mathrm{p}<0.05)$. Root length was highest for Red (semi-hard wood) and Double color (semi-hard wood) as they had $16.33 \mathrm{~cm}$ and $5.74 \mathrm{~cm}$ length.

Table 3 Effect of wood cuttings on wet root weight, dry root weight and root length of Bougainvillea spectabilis at I2WAP

\begin{tabular}{llll}
\hline Treatment & Wet root weight (g) & Dry root weight (g) & Root length (cm) \\
\hline Pink (hard wood) & $7.30 \pm .62 \mathrm{abc}$ & $0.92 \pm .39 \mathrm{a}$ & $8.25 \pm .43 \mathrm{def}$ \\
Red (hard wood) & $6.11 \pm .34 \mathrm{bcd}$ & $0.57 \pm .19 \mathrm{abc}$ & $12.30 \pm .5 \mathrm{Ib}$ \\
Double color (hard wood) & $4.00 \pm .55 \mathrm{de}$ & $0.33 \pm .09 \mathrm{c}$ & $7.28 \pm .7 \mathrm{lef}$ \\
Orange (hard wood) & $7.35 \pm .58 \mathrm{abc}$ & $0.60 \pm .49 \mathrm{abc}$ & $\mathrm{II} .30 \pm .4 \mathrm{Ibcd}$ \\
White (hard wood) & $3.84 \pm .52 \mathrm{de}$ & $0.38 \pm .07 \mathrm{bc}$ & $7.63 \pm .75 \mathrm{ef}$ \\
Purple (hard wood) & $8.95 \pm .58 \mathrm{a}$ & $0.70 \pm .09 \mathrm{abc}$ & $11.79 \pm .77 \mathrm{bc}$ \\
Pink (semi-hard wood) & $7.13 \pm .98 \mathrm{abc}$ & $0.38 \pm .04 \mathrm{bc}$ & $8.43 \pm .76 \mathrm{cdef}$ \\
Red (semi-hard wood) & $7.86 \pm .52 \mathrm{ab}$ & $0.73 \pm .54 \mathrm{ab}$ & $16.33 \pm 66 \mathrm{a}$ \\
Double color (semi-hard wood) & $3.30 \pm .52 \mathrm{e}$ & $0.41 \pm .55 \mathrm{bc}$ & $5.74 \pm .68 \mathrm{f}$ \\
Orange (semi-hard wood) & $5.16 \pm .45 \mathrm{cde}$ & $0.49 \pm .45 \mathrm{bc}$ & $1 \mathrm{I}$ \\
White (semi-hard wood) & $5.46 \pm .33 \mathrm{cde}$ & $0.33 \pm .22 \mathrm{c}$ & $6.7 \mathrm{bcd} \pm .7 \mathrm{lef}$ \\
Purple (semi-hard wood) & $5.43 \pm .64 \mathrm{cde}$ & $0.54 \pm .24 \mathrm{abc}$ & $9.14 \pm .78 \mathrm{bcde}$
\end{tabular}

Table 4 Effect of rooting hormone on stem girth of Bougainvillea spectabilis

\begin{tabular}{lllll}
\hline Treatment & Stem girth 3WAP & Stem girth 6WAP & Stem girth 9WAP & Stem girth I2WAP \\
\hline IBA & $0.36 \pm .02 \mathrm{~b}$ & $0.52 \pm .03 \mathrm{~b}$ & $0.66 \pm .04 \mathrm{~b}$ & $0.66 \pm .03 \mathrm{~b}$ \\
Coconut water & $0.48 \pm .04 \mathrm{a}$ & $0.67 \pm .05 \mathrm{a}$ & $0.84 \pm .06 \mathrm{a}$ & $0.83 \pm .06 \mathrm{a}$ \\
Tetracycline & $0.31 \pm .02 \mathrm{~b}$ & $0.47 \pm .02 \mathrm{~b}$ & $0.63 \pm .03 \mathrm{~b}$ & $0.72 \pm .03 \mathrm{ab}$ \\
Control & $0.12 \pm .02 \mathrm{c}$ & $0.30 \pm .02 \mathrm{c}$ & $0.48 \pm .02 \mathrm{c}$ & $0.42 \pm .02 \mathrm{c}$ \\
\hline
\end{tabular}

Effect of rooting hormone on stem girth of Bougainvillea spectabilis

The effects of rooting hormone on the stem girth of Bougainvillea spectabilis were significant $(\mathrm{p}<0.05)$. At week 3 , coconut water and the control had the highest and lowest stem girth of $0.48 \mathrm{~cm}$ and $0.12 \mathrm{~cm}$ respectively. There was no significant difference in the mean separation of rooting hormone and tetracycline on stem girth at week
3. At week 6 , coconut water and control has the highest and lowest stem girth of $0.67 \mathrm{~cm}$ and $0.30 \mathrm{~cm}$. There was no significant difference in the mean separation of rooting hormone and tetracycline on stem girth. At week 9, coconut water and control had the highest and lowest stem girth of $0.84 \mathrm{~cm}$ and $0.48 \mathrm{~cm}$. There was no significant difference in the mean separation of rooting hormone and tetracycline on stem girth. At week 12, coconut water and control had the highest and lowest stem girth of $0.83 \mathrm{~cm}$ and $0.25 \mathrm{~cm}$. 


\section{Effect of rooting hormone on leaf number of Bougainvillea spectabilis}

The effects of rooting hormone on number of leaves of Bougainvillea spectabilis were significant $(p<0.05)$. At week 3 , coconut water and control had the highest and lowest leaf number of 4.45 and 1.29. There was no significant difference in the mean separation of rooting hormone and tetracycline on stem girth. At week
6 , coconut water and control had the highest and lowest leaf number of 6.54 and 3.86 respectively. At week 9, coconut water and control had the highest and lowest leaf number of 9.29 and 5.90. At week 12, coconut water and control had the highest and lowest leaf number of 10.37 and 4.92 . There was no significant difference in the mean separation of coconut water, rooting hormone and tetracycline on stem girth as shown in Table 5 .

Table 5 Effect of rooting hormone on number of leaves of Bougainvillea spectabilis

\begin{tabular}{lllll}
\hline Treatment & Leaf number 3WAP & Leaf number 6WAP & Leaf number 9WAP & Leaf number I2WAP \\
\hline IBA & $3.60 \pm .22 \mathrm{ab}$ & $5.09 \pm .29 \mathrm{ab}$ & $6.91 \pm .37 \mathrm{bc}$ & $7.94 \pm .54 \mathrm{a}$ \\
Coconut water & $4.45 \pm .37 \mathrm{a}$ & $6.54 \pm .47 \mathrm{a}$ & $9.29 \pm .62 \mathrm{a}$ & $10.37 \pm .90 \mathrm{a}$ \\
Tetracycline & $2.88 \pm .17 \mathrm{~b}$ & $4.52 \pm .2 \mathrm{lb}$ & $7.40 \pm .28 \mathrm{ab}$ & $9.10 \pm .40 \mathrm{a}$ \\
Control & $1.29 \pm .14 \mathrm{c}$ & $3.81 \pm .19 \mathrm{c}$ & $5.90 \pm .24 \mathrm{c}$ & $4.92 \pm .35 \mathrm{~b}$ \\
\hline
\end{tabular}

Effect of rooting hormone on wet root weight, dry root weight and root length of Bougainvillea spectabilis

The effect of rooting hormone on wet root weight of Bougainvillea spectabilis was significant $(\mathrm{p}<0.05)$. The highest and lowest wet root weights were observed in coconut water $(7.04 \mathrm{~g})$ and control $(3.48 \mathrm{~g})$ respectively. There was no significant difference in the wet root weight of cuttings dipped in coconut water and tetracycline as shown in Table 6. The effect of rooting hormone on dry root weight of Bougainvillea spectabilis was significant $(\mathrm{p}<0.05)$. The highest and lowest dry root weight was observed in coconut water $(0.83 \mathrm{~g})$ and control $(0.23 \mathrm{~g})$ respectively. The effect of rooting hormone on root length of Bougainvillea spectabilis was significant $(\mathrm{p}<0.05)$. The highest and lowest root length was observed in coconut water $(12.05 \mathrm{~cm})$ and control $(6.88 \mathrm{~cm})$ respectively.

Table 6 Effect of rooting hormone on wet root weight, dry root weight and root length of Bougainvillea spectabilis at I2WAP

\begin{tabular}{llll}
\hline Treatment & Wet root weight $(\mathbf{g})$ & Dry root weight $(\mathbf{g})$ & Root length $(\mathbf{c m})$ \\
\hline IBA & $6.88 \pm .35 \mathrm{a}$ & $0.50 \pm .06 \mathrm{~b}$ & $9.77 \pm .47 \mathrm{~b}$ \\
Coconut water & $7.04 \pm .57 \mathrm{a}$ & $0.83 \pm .10 \mathrm{a}$ & $12.05 \pm .78 \mathrm{a}$ \\
Tetracycline & $6.56 \pm .26 \mathrm{a}$ & $0.56 \pm .04 \mathrm{~b}$ & $10.08 \pm .35 \mathrm{ab}$ \\
Control & $3.48 \pm .22 \mathrm{~b}$ & $0.23 \pm .04 \mathrm{c}$ & $6.88 \pm .30 \mathrm{c}$ \\
\hline
\end{tabular}

\section{Discussion}

In this study stem cuttings were used for propagation of Bougainvillea; hard wood and semi hard wood. The results revealed that the different stem cuttings had significant effects on the stem length, stem girth, number of leaves, root length, wet and dry root weight. It is well known that the success of rooting in the majority of ornamental plants depends mainly on the physiological stage of the mother plant, the time of planting of the cutting and the type of growth regulators used. ${ }^{7,8}$ also reported that sprouting is mainly attributed to the stored carbohydrates in the cuttings used for sprouting. The application of IBA improved rooting and root number as compared to untreated control. IBA has been reported to markedly increase adventitious root formation in many species. ${ }^{3,6,9-11}$ observed a similar trend in the vegetative propagation of Stereospermum suaveolens with cuttings treated with $0.2 \%$ IBA producing the longest root; results obtained by Carpenter and Cornell (1992) who, investigated the adventitious root proliferation response of three Hibiscus rosa-sinensis cultivars, found that rooting is highly influenced by IBA application duration and concentration. Gupta et al., ${ }^{12}$ reported that treatment of Bougainvillea cuttings with $1000 \mathrm{ppm}$ IBA gave maximum rooting $(100 \%)$ with higher number of roots in soaking method but its availability and cost of procurement by the peasant gardeners made it of utmost importance to conduct studies on local and accessible alternatives such as coconut water and tetracycline Okunlola; ${ }^{6}$ Panwar et al., ${ }^{13}$ observed the best rooting in hard woodcuttings of Bougainvillea var. Alok treated with IBA 2000ppm. Jadhav, ${ }^{14}$ observed more rooting percentage and number of roots from the stem cuttings of Phalsa when treated with IBA at $200 \mathrm{ppm}$. The study also ascertained rooting ability of the hardwood compared to the semi hardwood cuttings this is in accord with the results obtained by Ramadayal et al. ${ }^{15}$ who reported highest percentage of rooting, number of roots per cutting and root length from the hard wood cuttings of Bougainvillea variety Mary Plamer in response to the auxin. However with auxin application to the cutting, subsequent increase in the rooting may result in the increase of sprouting, this indirect effect of auxin on sprouting highlights the role of certain materials produced in the roots, responsible for sprouting. The increase in length of roots in cuttings treated with growth regulators may be due to the accumulation of metabolites at the site of application of auxins, cell enlargement, enhanced hydrolysis of carbohydrates, synthesis of new proteins, and cell division induced by the auxins Asl et al 2007. Cuttings treated with coconut water significantly increase shoot length, shoot girth, number of leaves, wet root weight, dry root weight and root length. Asma et al.. ${ }^{16}$ performed an experiment on In vitro propagation of kiwifruit (Actinidia deliciosa) using coconut water. During the study, it was observed that the root induction was highly effected by the length of shoots and an appropriate length was pre-requisite for the efficient root formation. The use of coconut water also indirectly effected In vitro roots induction since during shoot multiplication; the addition of coconut water to the culture media resulted in maximum shoot length (7.2 \pm 0.16$)$ and hence facilitating the efficient root formation. 
This enhanced root formation ultimately resulted in the high survival rate $(>95 \%)$ of the grown plants. Also, Agele et al., ${ }^{17}$ performed an experiment on coconut water dilution levels on yam vines cuttings and concluded that Coconut water at $5 \%$ dilution in water was found useful as a root-promoting substance for vine cuttings. The medium (coconut water) is rich in proteins, amino acids sugars, vitamins, minerals and growth hormones essential to promote tissue growth (George, 1993). Coconut water also contains myo-inisitol and microconstituent (phenyl urea), which enhances the activity of cytokines and also has IAA and Gibbrellic acid. ${ }^{17}$

Tetracycline (acetysalicylic acid or ASA) did not influence rooting of Bougainvillea cuttings though it is a potent plant hormone that stimulates the natural defense system in plants and has the ability to overwhelms disease pathogens by travelling through all parts of the infected plant thereby activating the immune system. ${ }^{18}$ However increase in the amount of ASA or frequency of use which is possibly damaging at higher application may be responsible for this however there is the need to conduct further research to estimate in what proportion ASA can be formulated for use as an alternative rooting hormone especially in Nigeria Okunlola. ${ }^{6-25}$

\section{Conclusion}

Rooting characteristics of cuttings of Bougainvillea was enhanced when soaked in coconut water and IBA while the uncontrolled and tetracycline soaked had no significant effect on the rooting ability of the cutting. Hardwood cutting used for propagation of Bougainvillea performed better in development in comparison with the semihardwood cutting of the plant.

\section{Acknowledgments}

None.

\section{Conflicts of interest}

The authors declared there is no conflict of interest.

\section{References}

1. Mohammed Ahmed Ali Fadwa, Hamid Ali Elbasheer Yahia Vegetative propagation of Peltophoriumpetrocarpum (DC) Backer ex k.Heyne: A multi-purpose tree. Net journal of Agricultural science. 2014;2(4):113-116.

2. Céline S, Luc N, Thierry B, et al. Proteomic Analysis of Different Mutant Genotypes of Arabidopsis Led to the Identification of 11 Proteins Correlating with Adventitious Root Development. Plant Physiology. 2006;140:349-364.

3. De Klerk GJ, Van Der Krieken WM, De Jong JC. The formation of adventitious roots; new concepts, new possibilities. In Vitro Cellular \& Developmental Biology-Plant. 1999;35:189-199.

4. Okunlola AI. The effects of cutting types and length on rooting of Duranta repensin the Nursery. Global Journal of Human Social Science, Geography, Geosciences, Environmental and Disaster Management. 2013;13(3):1-4.

5. Kesari V, Das A, Rangan L. Effect of genotype and auxin treatments on rooting response in stem cuttings of CPTs of Pongamiapinnata, a potential biodiesel legume. Current Science. 2010;98(9):1234-1237.

6. Okunlola AI. Effect of Media and Growth Hormone on the Rooting of Queen of Phillipines (Mussaenda phillipica). Nigerian Journal of Horticultural Science.2016;3(1):1-5.

7. Darwesh RSS. Studies on propagation of Ficus retusa cv. Hawaii, M.Sc Thesis, Faculty of Agriculture Cairo University, Egypt. 2000. 164 p.
8. Singh KK, JMS Rawat, YK Tomor. Influence of indole butyric acid (IBA) on rooting potential of Torch Glory Bouganvillea glabra during winter seasons. Journal of Horticulture Science and Ornamental Plants. 2011;3(2):162-165.

9. Hartmann HT, F Loreti. Seasonal variation in rooting of leafy olive cuttings under mist. Proc American Society of Horticultural Sciences.1995;87:194-98.

10. Blazich FA. Chemicals and formulations used to promote adventitious rooting. In: Davis TD, Haissig BE, Sankhla N, et al editors. Adventitious root formation in cuttings. Dioscorides Press, Portland, Oregon. 1988;32-149.

11. Baul TK, Mezbahuddin M, Mohiuddin M. Vegetative propagation and initial growth performance of Stereospermum suaveolens DC, a wild tropical tree species of medicinal value. New Forests.2008;37(3):375-283.

12. Gupta VN, BK Banerj, SK Datta. Effect of auxin on rooting and sprouting behavior of stem cuttings of Bougainvillea under mist. Haryana Journal of Horticulture Sciences. 2002;31:42-44.

13. Panwar RP, AK Gupta, JR Sharma et al. Effect of growth regulators on rooting in Bougainvillea var. Alok. International Journal of Tropical Agriculture. 1994;12:255-261.

14. Jadhav A. Studies on propagation of Phalsa (Grewia subinaequalis) by cuttings. M.Sc. Thesis. College of Agriculture Dharwad, University of Agriculture Sciences, Dharwad. 2007. 112 p.

15. Ramdayal P, AK Gupta, RS Saini, et al. Effect of auxin on the rooting of cutting in Bougainvillea var Mary Palmer. Journal of Forestry Research. 2001;20(2):171-173.

16. Asma N, Kashif A, Saifullah K. An optimized and improved method for the in vitro propagation of kiwifruit (Actinidia deliciosa) using coconut water. Pak J Bot. 2007;40(6): 2355-2360.

17. Agele SO, Ayankanmi TG, Kikuno H. Effects of synthetic hormone substitutes and genotypes on rooting and mini tuber production of vines cuttings obtained from white yam (Dioscorea rotundata, Poir). African Journal of Biotechnology. 2010;9(30):4714-4724.

18. Davies PJ. The Plant Hormones: Their nature, occurrence, and functions. In: Davis PJ, editor. The plant hormones: their nature, occurrence, and functions. Springer, Dordrecht. 2010;1:1-15.

19. Cerveny C, James G. Rooting hormones, Growers guide; Crop cultivation. 2005;36-44.

20. Day JS, BR Loveys. Propagation from cuttings of two woody ornamental Australian shrubs, Boronia megastigma and Hypocalymma angustifolium, Endl. (White myrtle). Australian Journal of Experimental Agriculture. 1998;38:201-206.

21. Leaky RRB, VR Charman, KA Longman. Physiological studies for tree improvement and conservation. Factors affecting root initiation in cuttings of Triplochitonscleroxylon K. Schum. Forest Ecology and management. 1982;4(1):53-66.

22. Rowezak MMA. Response of some ornamental plants to temperature with growth substances. M.Sc. Thesis, Faculty of Agriculture, Cairo University, Egypt: 2001. 54 p.

23. Wilson S, Thetford M. Principle and techniques of cutting propagation 1; Plant propagation, Pearson publisher inc. New Jersey: 2011.

24. Sherer VK, RS Gadiev, AF Vorobeva, et al. Growth regulating activity of various chemical compounds of grapevine rootstock cuttings. Vin Org AdarsalvaiVinodelie. 1985;28:12-15.

25. Wahab F, G Nabi, N Ali, et al. Rooting response of semi-hard cuttings of guava (Pisidium gujava) to various concentrations of different auxins. Journal of Biological Sciences. 2001;1(4):184-187. 